\title{
MOĞOL KANUNLARI
}

\author{
Yazan: Dr. Iur. Curt ALINGE Çevirlen: Prof. Dr. Coß̧kun ÜÇOK
}

III. B Ö L Ü M

\author{
3. KESIIM
}

\section{$\S 2$ - CEZA HUKUKU \\ I. - Genel olarak 、}

Kanunun acaba hangi hükümleri ceza hukukuna ait saylmalıdır? Tabiatiyle kanunun terviç etmediği bir vakıaya zararlı bir netice bağladığı veya böyle bir zararlı neticeyi doğrudan doğruya menettiği hükümleri bahse konu olabilirler. Müsbet olarak bu hususa kolayca şöyle cevap verilebilir: kanuna aykın ve kusurdan doğan hangi fiillere, bunlar ister devlete ister özel menfaate karșı işlenmiş olsun, bir ceza müeyyidesi konulmuşsa böyle müeyyideleri ihtiva eden hükümler ceza hukukuna aittir. Burada cezanın cismanî veya malî olmasının, malì cezanın da devlet tarafindan alman veya zarar görene ödenen bir ceza olmasının hiç bir solü yoktur. Buna karșlık bazı hâllerde - ki bunlar hep bir insanı ölümii ile ilgilidirler - zararlı netice sübjektif kusura bağlanmamıştır. Zararlı neticenin var saylması için, ister bir başkasının kusursuz hatasından ( 5 , $11 . \S)$, ister tesadüften $(6,9 . \S)$ hatta ister meçhul bir üçüncü şahsin fiilinden ( $6.16 \S)$, veya hayvanlarn fiilinden $(6,13-15 . \S)$ doğmus olsun kanuna aykın objektif bir neticenin mevcut olması yeter saylmıştır. Bu gibi fiillerin bir kısmı $(6,9 ., 10 ., 13 ., 14 . \S)$ doğrudan doğruya ceza hukukuna girmektedirler, cünkü failin sübjektif bir kusurunun mevcut olmasına rağmen, Moğol kanunu failin filinin neticesini suç kabul etmekte yâni onu cezalandırmaktađ̊̉r. Geri kalan hâllerde ise $(6,11 ., 12 ., 15-17$. § ) sübjektif bir kusur olmadan meydana gelen kanuna aykın netice (ölüm) yalnızca varislere tazminat ödemek mecburiyetini tahmil etmektedir. Ancak, ölçüsü başka olmakla beraber taammüdlü öldürmelerde de ceza olarak karşımıza çıan bu tazminat, o za- 
manki hukuk anlayışı göz önünde tutulursa cezaî bir mahiyet taşımaktadır. $\mathrm{Bu}$, özel hukukta her duruma göre tâyin edilen tazminatla mukayese edilemez. Bu daha ziyade kanunun önceden tâyin ettiği ve özel intikamı önlemeğe yarıyan bir diyettir. Demek ki bahse konu olan şey, borçlar hukukundaki kusursuz mesuliyetle kiyaslanamyacak ve ceza hukukunda kökü bulunan özel intikamdan çkma bir unsurdur, yâni cezai bir mesuliyettir.

Böylece ceza hukuku, yalnız suçtan ötürü mesuliyeti içine almayıp sübjektif bir kusur olmadan da meydana gelen haksız neticeleri içine aldrğından, hemen ceza hukukunun, tamamiyle netice mesuliyeti prensibinin tesiri altında bulunduğunu iddia etmek yerinde olmaz. Bununla beraber çoğunluğu teșkil eden hâllerde "adamı fiil öldürür" prensibi hâkimdir. Teşebbüs $(2,5$. § hariç $)$ ve teşvik'den hiçbir yerde bahsedilmemisttir. Gene de istisnalar mevcuttur: bir kere az da olsa cezayı kaldıran durumlarda: meşru müdafaa $(6,18$. §), ( gene her hâlde meşru müdafaa sırasında sayılması gereken) herkesi tehdit eden bir delinin öldürülmesi $(6,19$. § ), uyruklardan birinin prenslerden birinin hizmetkârlanı tarafından öldürülmesi $(2,7 . \S, 2$. bend), cezaya tâbi olmıyan iki maddi zarar hâli $(12,3 ., 6$. § ); bunlardan başka - mahiyetleri icabı neticeden mücerret olarak - ihmalì suç $(1,5 .-7$. $)$; nihayet bazı kasit ve kusur ( dolus, culpa ) gibi şeylerin ceza filinin unsuru sayldığı ve bunlarn bulunmayışııın mevcut haksız neticeye rağmen, fiilin cezalandırılmamasına yettiği bütün hâller ( $\mathrm{msl} .2,4 . \S ; 12,1 ., 4 ., 5 . \S)$.

Cezaların bir kısmı misillemeye yarayan kamu cezalan, bir kısmı - özel menfaatlarn zarara uğraması hâlinde - tamamiyle maddì zararın tazminidir, bir kısmı ise bir devlet misillemesi ile özel tazminatın karş̧ması hâlinde karşımıza çıkmaktadır. Durumların çoğunda cezalar maî̀ cezadır ve bunlar çok kere sığır, nadir olmuyarak da askerî techizat ( zırh ve silahlar ) veya az veya cok değerli ev esyası vermek mecburiyetinden ibarettir (1) X. Bilhassa ağır suçlarda belli malî cezanın yerini, bütü:x

1) Kaide olarak sığır cezalar ya 9 yahut dokuzun bir kaç misli veya 5 sığır olarak zikredilmiştir. Dokuz sayısı eskiden beri mukaddes bir sayı sayılmakta ve 9 at cezası Yasa' da bile (29.Fr) bulunmaktadır. Kanunun 9 veya 5 sığırdan ne kastettiğini bilmiyoruz. Aynı ceza Halha-Cirom (IV. Ek) ve Çinliler tarafından 1789 'da Moğolistan için çıkarılmış olan kanunda da bulunmaktađır (V. Ek). Her iki kanun kitabında bunun ayrı aym mânaları vardır (bk, aș. ve V. Ek, XII. Bölüm 1. Madde); ancak daima bahse konu olan 9 veya 5 aynı cins olmıyan sığırdır, her hâlde Oyrat-Moğol Kanunu için de hâl böyledir. Birçok yerlerde malî ceza olarak önümüze çıkan "askerî teçhizat", Pallas'a 
malların ( $1,2 . \S ; 4,3 . \S ; 4,10 . \S$ II; $6,2 . \S ; 8,11 \S)$ veya bunun yarısının müsaderesi ( $1,7 . \S$ III; 3, 3. $\$ ; 21,2 . \S)$ almaktadır. Birçok hükümlerde karşılaştığımız, mal ve mülkün tahrip edilmesi cezası da bununla yakından ilgilidir ( 1 , II $\S ; 6,3$. $\S$ II; her hâlde 17 de ). Mahiyetleri icabı bu malî cezalann bir kısmı kamu cezası, bir kısmı ise kanışı kamu cezası ve özel cezadır. Her yerde, buradaki sınırı emniyetli bir şekilde çizmek mümkün değildir. Şüphesizdir ki, kamu menfaatine zarar veren suçlarda malì cezalar prensin hesabına ( veya suçlu prens ise, diğer ilgili prenslerin hesabına) tahsil edilmekteydi ( msl. 1, 3. §; 21, 6. $\S ; 1,2$. $\S$ I ). Bununla beraber uyruklar da bundan faydalanabilirlerdi $(1,2$. $\S$ II). Özel menfaatin haleldar edildiği bir sıra durumlarda cezanın mahiyetinin de. özєl olduğu ( tazminat) açıç̧a tesbit edilmiştir: ceza zarar görene ödenmektedir ( $m s l .4,10$. § II; 6, 11., 12. §; 13, $3 . \S ; 15,5 . \S ; 16 ; 18,1 . \S)$. Nihayet kanun, sığır hırsızlığından ötürü ödenmesi gereken sığır cezasının bir kısmının hırsızlığa uğnyana, geri kalanin ise, prense ödenmesini $(8,1, \S)$ başka bir yerde de ( $|B| I I$, 15. § ) dâvada kazanan müddeinin, müddeaaleyhin mahkûm edildiği malî cezamı dokuzda birisini almasın, artanın gene prense verilmesini emretmektedir. Demek ki bütün bu durumlarda ceza hem özel bir karakter hem de bir kamu karakteri taşımaktadır. Birçok durumlarda cezanın mahiyetinin ne olduğunun anlaşılamadığı da nadir değildir: msl 5, 1. § Il'de 9 adet sığınn, akrabalara verilen bir tazminat olup olmadığı sorulabilir; eğer bu böyle değilse ve eğer - ki akla daha yakındır - burada da bahse konu olan tamamiyle bir kamu cezası ise, o zaman - B II, 15. $\S$ uyularak - nasıl bu sığırların dokuzda biri kazanan müddeilere verilebilirdi? Çünkü bahse konu olan sığırlar aynı cins ve aynı değerde değildirler ( bk. 1. numaralı nota ).

Malî cezaların yanında diğer cezalar çok az bir yer almaktadırlar. Ölüm cezası yalnız bir yerde anılmıştır $(1,5$. $\S$ - hatta burada bile esir muamelesine tâbi tutulmanın anlatılmak istenip istenmediği sorulabilir; ölüm cezasından açıkca yalnız askerî kanunlarda, savaş sırasında prensi terketmenin cezası olarak bahsedilmiştir B IV, 2. §, 2. fikra ). Diğer

göre (I. Bölüm, S. 145) şunlardan ibarettir: 1) omuzlara kadar inen halkal: ve çelikten bir ağla birlikte bir miğfer, 2) kollu zırh gömlek, 3) iki tane çelikten kol bağı. İran işi iyi bir zırh gömlek 50 at değerinde sayılırdı. "Bir erkeğin silâhları" şunlardır: "mızrak, yay ve oklarıyla birlikte ok kabı, kama ve kılıç" (Pallas I. Bölüm, S. 143 v. öt). "değerli bir şey" den ne anlașılmaik gerektiğini (msl bk. B. 16, 13. §) hiç olmazsa kısmen öğrenmek için belki $B$. I 8,7 . § da sayılmıs olan şeyler bir fikir verebilir. 
cismanî cezalar da nadirdir: sakatlama $(4,5 . \S ; 8,8 . \S ; 21,8$. §) ve kurbaç darbeleri ( $4,7 . \S ; 13,1 . \S$ ). Sahsiyeti kaybetme ( esir olma) diğer ağır cezalarla birlikte görülmektedir $(1,7 . \S ; 4,5 . \S ; 8,11 . \S)$, sonra geçici olarak şahsî hürriyetten mahrumiyet ( prangaya vurulma ), $(21,8 . \S, 2$. fikra ) ve nihayet memuriyetten atılma $(21,4 ., 5 . \S)$.

Bazı durumlarda faille birlikte veya onun yerine karısı veya ailesi de ceza çekmektedir ( $1,7 . \S, 1$. fłkra; 4,10 . $11 ; 6,2 . \S ; 8,11 . \S)$.

Yasayla karşılaştınlınca, buradaki cezalar hafif görünmektedirler. Haklı olarak, ceza hukukunun daha insanî bir şekil almasını sebebleri arasında budizmin az olmiyan tesiri hesaba katılmalı, ancak daha eski Tsaayin Biçik zamanında da, Yasa zamanınkinden daha musamahalı bir görüşün hâkim olmuş bulunduğu da unutulmamalıdır. Sakatlama ve bütün ailenın sorumluluğu gibi bazı yenilikler Çin tesiri altında kabul edilmiş olmalıdır.

Kanun, kanun önünde eşitik prensibini tanımamaktadır: rahipler, prensler ve diğer sınflann ileri gelenleri hakkında birçok özel hükümler mevcuttur.

Tamamiyle kasüstik bir metotla hazırlanmıs olan kanun - belki de istenilmiştir de - bu metotun icabı olarak tam olmaktan çok uzaktır. Bununla beraber kanun bize, o zamanki Moğol göçebelerinin hayatında hangi suçların daha çok tekerrür ettiğini ve bundan ötürü de bunlann yazılı bir kanunla tespit edilmeğe değer bulunduğunu göstermeğe yetmektedir.

Müníerit kaideler tarafımdan suç kategorilerine göre tanzim edilmişlerdir $\left(^{2}\right)$. Bununla beraber, kanun tarafından imtiyazlı sayılan bazı șahıs gruplarına ( prensler, rahipler ) ve aile topluluğuna karşı işlenmiş sayılan suçlar ayrıca gösterilmiştir ( 2.-4. kesimler ).

\section{II. - Suçlar ve jeezalkłrt.}

1. Ayrım: Devlete karşı işlenen suçlar.

1640 yılı prensler toplantısının başlıca gayesi, dış düşmanlara karşı tesirli bir sekilde savunmak için bir birlik kurmak ve bu birliği, birliğğin bütün üyelerini bağlıyan kanunlarla sağlamlaştırmak olduğuna göre,

2) Bununla beraber vakıaların incelenmesinde, kanunun bizim aynı husustaki. anlayışımızdan ayrıldığı noktalarda kanunun anlayışına uyulmuştur (msl. Sodomi ahlaka karşı işlenen bir suç değil, maddî zarar olarak sayılmıştır). 
bu toplantının başlıca vazifelennden birisi de biriğin veya üyelerinin bekasın tehdit edebilecek fiillere verilmesi gereken cezalan tespit etmekti. Gerçekten de kanun koyucular bu gurup cezayı mucip fiilleri etraflıca tespit etmekle vazifelerini yapmağa çalışmışlardır.

Bununla ilgili kaideler şöyle aynlabilir:

(I) Birliğin veya bunun üyelerinden birisinin emniyetine karşı işlenmiş olan fiiller.

(II) $\mathrm{Bu}$ emniyeti temin için gereken fiillerin yapılmasının ihmal edilmesi.

Her iki grupta da fail olarak ortaya şunlar çıabilir:

(a) Birliğin üyesi olmak dolayısiyle prensler.

(b) Birlik prenslerinin uyruklan.

(I) (a) Toplantıda kabul edilmiş olan kanunların topu birden birliğin sağlamlaşması yolunda önemli bir vasıta olarak düşünülmüştü. Birlik üyeleri tarafindan bunlann keyfi olarak değiştirilmesi, bundan ötürü birliğin temellerinin tehdidi mânasını taşımakta idi ve ceza ile teyit edilmişti (1. §). Prenslerin rütbelerine göre basamaklı bir şekilde tespit edilmiş olan sığır cezalan hemen hemen sözde kalmaya mecburdu, çünkü hükümdar yetkilerini haiz bulunan bir prensin bu ceza olarak verilmesi gereken sığırlan uyruklanndan toplayıvermesi pek de güç bir şey değildi.

Birliğe karşı işlenebilecek en büyük suç, tabiidir ki, üyelerden birinin diğerine karşı açıkça savaş açması idi. Bundan ötürü kanun koyucular her şeyden önce, Moğol hâkimiyetinin yrkılmasına sebeb olan vs yüzyıllarca aşiretlerin kuvvetini yiyip bitirmiş olan bu kötülüğü ortadan kaldırmayı düşünmüştüler. Ancak burada bile kanun, birliğin en şiddetli bir şekilde tehdidi demek olan bu duruma karşı bile gereken sertliği gösterememiştir: her nekadar enerjịk karşı tedbirler düşünülmüş ve suçluyu daimî olarak zararsız bir hâle getirecek bir ceza da konunlmuşsa da, suçlu prense asıl tesir edecek olan ölüm cezası konulamamıştır (2.\$).

(b) Buna karşllı bozkır aristokrasisinin entrikalan pek önemli görülmemiş ve bundan ötürü de küçük cezalarla teyit edilmiştir (3.§). Diğer taraftan ceza o kadar az tespit edilmiştir ki, 1. § konulmuş olan ceza kadar insanın tuhafına gitmektedir. Gerçekten de büyük sürüler sahibi bir kimse için bir deve ve 20 sığınn ne değeri vardır! Buna karşı- 
lık gene aynı kimseler, entrika sınınnı aşarak faal bir şekilde küçük çapta savaşlara başlar, sınırların emniyetini bozar, sürüleri alıp götürürlerse ağır malî cezalara çarptırılmakta, aynca gaspettiklerini de geriye vermeğe mecbur tutulmaktadırlar (4.\$).

(II) Bununla beraber yalnız iç sükûn bütünün emniyetini temine yetmez, dışardan düşman tehdidi baş gösterince de herkesin birlikte hareket etmesi gerekmektedir. Bundan ötürü böyle durumlarda yardımdan kaçanlara ait bir sıra hüküm konmuştur.

(a) Böyle durumlarda yardımı reddeden prensler bilhassa cezaya müstahak sayılmıslardır. Bununla beraber kanun koyucular burada bile ölüm cezası ile tehdide cesaret edememişlerdir. Görünüște oldukça yüksek olan malî cezayı ise (6. §) gerçekte, suçlu prens kolayca uyruklarından toplayıp verebilirdi.

(b) Alelâde bir adamın msl. bir çobanın, sınırda oturduğu için düşmanın yaklaştığını öğrenip de gereken makama haber vermemiş olması suçu yukardaki suçtan hiç bir şekilde daha ağır olmadiğı hâlde, burada - ki suçlu hiçbir zaman bir prens olamazdı - suçlu "düşman olarak" yâni ölümle cezalandınlmaktadır ( belki de esaretle; 5 . $\S$ ).

En büyük tehlike anında, düşmanın yaklaştığını görüpte, haber vermeği ihmal edenler çok ağır cezalar ile cezalandırılmaktadırlar. Bu gibilerin varı yoğu yağma edilmekte, kendisi ve ailesi esir olmaktadırlar ( 7. § I, 1. fłkra ). Burada da ağır ceza yalnız ( 5 . § olduğu gibi ) uyruklara verilmektedir.

Savaş haberinin duyurulması bütün eli silâh tutanların, prenslerinin kışlasına gitmeleri mecburiyetini tazammun etmekteydi. Böyle bir şekilde gitmeyenlerin mallan müsadere edildiği gibi kendileri de hürriyetlerini kaybederlerdi ( esaret; 7. §, I 2. fikra ).

Bunun gıbi, düşmanın hücum ettiğini duyan herkes yardımla mükellefti. Bununla beraber bunu ihmal edenlere verilen - ve suçlunun malî durumuna göre basamaklı olan - malî cezalar küçüktü. Yalnız asilzadeler için burada "noblesse oblige" kaidesi tatbik edilmekteydi: bunlar mamelekelerinin yarısını kaybetmekteydiler ( 7. § III ).

Yardımın ihmal edilmesi nasıl cezalandırılyyorsa, diğer yandan da hücuma uğrayanlara yapılan yardıma - vekâleti olmadan başkası hesabına tasarrufta olduğu gibi - iyiliğin mükâfatlandırılması prensibi uygulanmakta ve savaşta ölenlerin varislerine de tazminat verilmektedir (7. § II).

Kanun koyucunun, birliğin dokunulmazlığını ve iç sükûnu temin 
yolunda koymuş olduğu etraflı kaidelerden, bu hususa ne kadar önem verdiği açıkca anlaşllyyorsa da tespit edilmiş olan malì cezalann hafifliği, o zamanlar, adı geçen birçok durumlarda ancak tesirli olabilecek ölüm cezasını kabul ettirebilecek ve bu suretle de kanuna gereken saygiyı sağlayacak hâkim bir şahsiyetin mevcut olmadığı görülmektedir. Kanunun bu zayıflı̆̆ bilhassa prenslerin işlediği suçlarda kendisini göstermektedir; bunlara kendilerinin hemen hiç hissetmiyecekleri kadar hafif cezalar verilmekte hatta en ağır suçta bile ( 2 \$) ölüm cezasını koy. maya cesaret edilememektedir. Halbuki çok kere âsi prensler topraklannı ve mallarını kaybettikten sonra, komşu bir aşiretten asker toplamış ve eski topraklannı tehdit etmişlerdi! Bununla beraber bu toplantiya katılmıs olan yüksek lamaist rahiplerin ölüm cezasını budist doktrinine aykırı saymış olmalarının tesirleri de belli olmaktadır. Ancak herşeyden önce, her türlü mukavemeti ykkacak ve hatta rahiplerin kudretli sesine bile karşı koyabilecek olan bir Cengiz Han'ın eksikliği hissedilmekteydi.

\section{Ayrım: Prenslere karşı işlenen suçlar.}

İstibdatla hüküm sürmekte olan prenslerin kendilerini, koruyucu bir sıra hükümle bezemeleri hiç şüphe yok ki, o zamanki durumun ve çok gevşemiş olan disiplinin bir nişanesidir. Bahse konu olan şey, yalnız prenslerle uyruklar arasındaki mesafeyi muhafaza etmek değildi. Hükümler, açık bir şekilde, kızmıs olan insanların hükümdarlara karşı fiilen tecavüz ettiklerini $(1 . \S, 2)$ ve halkın kızgunliğının bazan da kendisini, prenslerin memur ve hizmetçilerine tecavüz suretiyle açığa vurmuş olduğunu göstermektedir (7. §).

Kanun şunlan himaye etmektedir: (I) bizzat prensleri ya (1) hakaret ve kötü muameleye karşı yahut da (2) maddì zararlara karşı; (II) Prenslerin hizmetlerinde bulunan memur ve hizmetçileri ise her türlï hakarete karșı.

(I) (1) Prenslere hakaret veya kötü muameleden ötürü verileı cezalan, prenslerin rütbeisine göre değişmektedir. Büyük prenslere sözle hakaret, suçlunun bütün mülkünün tahrip edilmesiyle cezalandınldı̆ğı hâlde, orta ve küçük prenslere hakaret ile kötü muamele arasında bir aynm yapılmış, bundan başka küçük prenslere aynıca kötü muamelede de, hafif ve ağır darbeler ayn ayn hükümlere uyruk tutulmuştur. (3).

3) Kanun muntazaman ağır, orta ve hafif darbeler arasında bir fark yapmaktadır (msl. bk, B7, 3. ve 4. §). Kötü muamelenin hangi dereceden ol- • 
Başlı başına bir memur sınıfı teşkil eden ve anlaşılan zorbaca hareketleriyle tanınmış olan postacı süvariler hakkında da ayrıca bir hüküm vardir ( bk. B III, 16.-19. § ). Burrada da cezalar, hakarete uğnyanın rüłbesine göre basamaklandırlmıștır; ancak bunlar genel cezalar katalogunda (1. §) anılmış olanlardan oldukça hafiftirler (2. §).

Yasa zamanında nasıl bir komutanın eşiğini atlamak en ağır ceza ile cezalandırıliyor idiyse (32. Fr.) Oyrat-Moğol Kanunu da bir pren. sin ateş bölgesi içinde bir kazık çakana oldukça’ ağır cezalar (sığır cezaları) koymuştur; bu hareket bir hakaret, prensin hükümranlık hakkına bir tecavüz sayılmaktaydı (3. §). 4. § da prensle uyrukları arasındaki mesafeyi göz önünde tutmaktadır. Ancak bu madde kanundaki şekliyle pek de anlaşılır gibi değildir; çünkü bir çadıra, hele bir prens çadırına hayvanlar hiçbir zaman giremezler. Her hâlde burada kasdedilen şey prensin çadırının etrafında bulunan ve karargâhı içinde kendisine aynlmıș olan bölgedir ve buraya yetkisi olmıyanların atlanyla girmeleri menedilmiştir. Böylece "bilerek kirletmek" tâbirini "yetkisiz olarak girmek" diye anlamak gerekir.

(2) Vergi memurlan (Zaisanlar) tarafindan tahsilatın zimmete geçirilmesi veya prenslere muayyen zamanlarda verilen aynî vergilerin zimmete geçirilmesi veva çalınması prensleri tehdit eden maddi bir zarardı. $\mathrm{Bu}$ cinsten suçlara karşı 5 . § konulmuştur. Bu madde, bütün kanunda teşebbüsten bahsedilen yegâne maddedir. Burada konulmuş olan çok ağır sığır ödeme cezası, bu gibi gayrì ahlakî hareketlerin önüne geçebilmek için ne kadar gayret sarfedildiğini açıça göstermektedir. Prenslere bu yolda zarar verilmesinin bir şekli de aynî vergileri vermek veya bunları taşımakla mükellef olanların bunlan vermek veya taşımayı savsaklamaları ve böylece yiyecek sevkiyatını arasıra kesmeleri ile mümkün idi. Buna karşılık 6 . $\S$ konulmuştur ki bunda da zarar görenin rütbesine göre basamaklı sığır cezaları vardır.

(II) Prens, hizmetinde bulunan memur veya saray hizmetçilerine yapılan tecavüzlerle de, dolayısıyla hakarete uğramıs olabilirdi. Bu gibi şahıslan himaye için konulmuş olan 7. §'daki hüküm hiç şüphesiz halkın tâbi tutulmakta olduğu ve ağir vergiler ve diğer keyfî hareketler hâlinde tecelli eden ağır baskı ve prens memurlarına ve hizmetçilere karṣı bunun doğurduğu kin ve nefretle ilgilidir. Kanun tamamiyle tek tarafl olarak

duğunu mahkeme kendi müşahedesi ile veya tronlk ifadelerine göre tâyin . ederdi (BII, 6. $\$$ ). 
prensin hizmetinde bulunanlan tutmakta ve bunlara, tecavüz karşısında mütecavizi cezasız bir şekilde öldürme yetkisini vermektedir. Kavgada bunlar altolsalar bile, suçlunun kim olduğu araştınlmadan kendilerine oldukça büyük bir tazminat verilmektedir ( 9 sığır).

\section{Ayırım: Rahip sınıfına karşı işlenen suçlar.}

Kanun koyucu kurultay toplantı hâlinde bulunduğu sırada, lamaizm artık Moğolistan'da iyice yerleşmiş bulunmakta idi. Geniş araziye ve birçok Şabinar'a sahip manasturlar meydana gelmiş, ilk Hubilgan'm gözüktüğü bildirilmişti; rahipler büyük bir saygı görmekte ve büyük rahip sınfi bizzat prensler kurultayına katılmaktaydı. Bu ayrimda incelenen hükümlerin meydana gelişinde bu rahiplerin büyük nüfuzunun tesiri olduğu şüphesizdir.

Bu hükümler (I) rahip sınıfnı gene rahiplerin tecavüzüne, (II) rahipleri hakaret ve kötü muameleye ve (III) manastırlann mülklerini tecavüze karşı himaye etmek için konulmuşlardır.

(I) Rahip sınıfına gene rahiplerin tecavüzü şu şekilde anlaşılmakta idi: (a) dinî bir adağın kasden yerine getirilmemesi (4), (b) rahiplik rütbesinin bırakılması, yâni mecburî bir sebeb olmaksızın ve daha yüksek dinî makamın gereken müsaadesi alınmaksızın rahiplik sınıfının terkedilmesi (1. §). Buradaki olağanüstü ağır ceza (bütün malların yarısının müsaderesi) yeni dinin bildiricilerinin kendi sınıflarmın temiz kalması ve disiplini için sarfetmekte olduklan gayreti göstermektedir.

(II) Hakaret ve kötü muameleye karşı bütün rahipler ve din adamları, (rahip talebeler ve rahibeler' ve tek bașina yaşıyan dindarlar da dahil olmak üzere) sığır cezalan ile himaye edilmişlerdir. Bu cezalar da hakarete uğrıyanın rütbesine göre basamaklıdırlar ve bilhassa kanunun bu gibi ve buna benzer diğer suçlarda koymuş olduğu cezalardan, büyük rahiplerin hakarete uğrayışlanında verilen cezalar çok daha ağırdır (5). Kötü muamelede ceza, durumun vehametine göre yargıç tarafindan arttrrılmaktadır (2. §). Buna karşlık rahip sınıfına alınmış bir din adamının yâni bìr Gelsul veya Gelong'un kötü muameleye maruz kalması hâlinde verilecek ceza kanun tarafından tespit edilmiştir: bütün mallann

4) Kilise tarafından bir adağın ihlâl edilmesi hakkında bk. yk. ve I. Bölüm, 2. Kesimin 4, notuna.

5) Mukayese için: 
yarısının müsaderesi (6) (3. §). Rahip sminna eskiden mensup olup da evlenmiş olanlar da bu suçlara karşı himaye edilmişlerdir, yalnız burada verilen cezalar oldukça hafiftir $(5 . \S)$.

Postacı süvariler, at verme mükellefiyetinden muaf tutulmuş olan rahip sinffina mensup şahıslarn atlarnna el koyacak olurlarsa bu, dinî imtiyazlara riayetsizlik sayllyordu. 4 . $\S$ bununla ilgilidir ve bu imtiyazı ihlâl eden bu gibi postacı süvarileri ceza ile tehdit etmektedir (ancak ceza oldukça hafiftir). Buna karşllk dine tahsis edilmiş atlara binmek . ki kanun bundan da aynca bahsetmektedir - rahiplerin menfaatlerini ihlâl etmek değil, doğrudan doğruya dinì bir suçtur. Din adamlarna ait olmyan atlar (hatta bazı diğer hayvanlar) sahiplerinin arzusu üzerine, kötülüğü uzaklasstırmak üzere bir Burhan'a (Budda'ya) adanırd. Bundan böyle bu gibi hayvanlara dokunulmamak gerekirdi ( bk. Pallas II. Bölüm, S. 322 v. öt. ). Buna aykırı harekette postacı süvarilere ( veya bunlar tarafından bir at tedariki hususunda sıkıştırılmış olan at çobanlarına ) verilen ceza oldukça hafif tutulmuștu, çünkü burada suçlu her zaman ișinin, yâni götürmekte olduğu haberin çok önemli ve acele olduğunu ileri sürebilirdi. Hatta postacı süvari bir suçu olmadığımı yeminle teyid ederek cezadan da kurtulabilirdi (4. §).

(III) Rahiplerin teker teker özel mallarını kanun ayrıca korumamıştır. Her nekadar 6. §'da rahip sınfı mensuplarına verilmiş olan zararlardan bahsedilmekte ise de (ister vücude ister mala verilmiş bị zarar olsun), konulmus olan ceza burada münferit rahiplerin menfaatlerinin

\begin{tabular}{|c|c|c|c|}
\hline Hakarete uğriyan & Hakaretin cinsi & ceza (sığır) & $\begin{array}{c}\text { kanundaki } \\
\text { yeri }\end{array}$ \\
\hline büyük rahip & sözle & $9 \times 9$ & $3,2 . \S$ \\
\hline küçük rahip & sözle & $5 \times 9$ & $3,2 . \S \mathrm{II}$ \\
\hline Ubași, rahibeler & sözle & 5 & $3,2 . \S \mathrm{III}$ \\
\hline orta prens & tecavüzle & $5 \times 9$ & 2. $1 . \S$ \\
\hline orta prens & sözle & 5 & $2,1 . \S$ \\
\hline Ana-baba & ağır tecavüzle & $3 \times 9$ & $4,2 . \S$ \\
\hline Kadın & $\begin{array}{l}\text { başlıktan ponponun ko- } \\
\text { parılması }\end{array}$ & 9 & $15,3 . \S$ \\
\hline Alelâde hür & $\begin{array}{c}\text { yumruk veya kırbaçla } \\
\text { ağır tecavüz }\end{array}$ & 5 & $7,4 . \S$ \\
\hline
\end{tabular}

6) Büyük rahiplere karșı sözle hakaretten daha önce 2, § I'de bahsedildiği için "rütbeye tecavüz", fiili tecavüz veya kötü muameleden başka türlü anlaşlamaz. 
ihlâl edilmesinin bahse konu olmadığını göstermektedir. Burada esas ceza 1 . $\S 4$. ncü bendinde bahsedilen ve küçük çapta savaşlar, büyük çapta çapulculuk, sığır sürülerinin alınıp götürülmesi vsr. ye karşı konulmuş olan cezadır. Buna uygun olarak 6 . $\S$ da manasturlann, bunlarnn toprak, ve sürü vsr. mallarının adı geçen cinsten tecavüzlere karşı korunulma. $s:$ şeklinde anlaşılmak gerekir. Bu gibi tecavüzlerden iç kargaşahı̆ın alıp yürüdüğü o zamanlarda manastırlar da çok zarar görmekte olmalı idiler. Bununla beraber rahip sınifina mensup olmiyanlann menfaatlerine nispetle vakıflarn menfaatleri çok daha büyük bir himayeye mazhar olmuşlardır. Öyleki esas ceza aynı kalmakla beraber burada gaspedilenin iki misli geri verilmekte, ayrıca kötü mallar yerine iyisi, ayıplı mallar yerine de ayıpsızı verilmektedir.

\section{Ayrım: Aileye karşı işlenen suçlar.}

Aileyi kanun şu şekillerde korumaktadır: (I) ailenin iç sükûnunı gene ailenin üyelerine karşı himaye etmekte ve ana-baba otoritesini hiçe saymayı cezalandırmakta, aynca yakın hısımlan yaralama ve öldürmeyi de özel hükümlere bağlamaktadır. (II) Ailedeki otorite durumunun aile dışındaki kimseler tarafından ihlâli de cezalandırılmaktadır. Bunun da şu şekillerde olacağł kabul edimiștir: (a) zina ve kanun tarafından zinanın bir nevi saylan evli bir kadına tecavüz ve (b) aile reisinin arzusu hilâfına, kendisi için bir satış konusu veya çalışma kuvveti sayılan' kızın veya karıların alınıp götürülmesi (kadın kaçırılması veya gaspı).

(I) Aile reisinin otoritesini itaatsizlik veya karşı koyma ile bozan çocuklar prensin önüne çıanlıp bunlardan şikâyet edilecektir. Konulmuş olan cezadan (tam bir savaş teçhizatı ve 9 sığır) kanun koyucunun yalnız oğullan kastettiği hükmü çikanlabilir: erginler cezayı kendi mallarından ödemektedirler. Babalannın velâyeti altında bulunan oğullarda ise, bu, mıras hisselerinden ödenmekteydi ki, bu da ancak evlenme çağında olan erkek çocuklarda bahse konu olabilirdi. Zira kaide olarak evlenmemiş oğullar ana-babalarından aynlıp - her hâlde evlatlık olarak başkalarını yanına gitmekteydier (1. §). Itaatsizlik, kötü muamele ve tecavüz hâlini aldığı takdirde, suçun ağırlığına göre gittikçe artan basamaklı cezalar konulmuştu( ${ }^{7}$ ) (2. §). Tedip hakkının sınırlannı aşan babasını öldüren oğul, bütün malını (ve miras hissesini) kaybederdi (3. §). Meşru müdafaa böylelerini cezadan kurtaramazdı.

7); 2. §'da zikredilmiş olan üç cezanın ( 9 sığır, $2 \times 9$ ve $3 \times 9$ sı̆̆ır) hafif orta ve ağır derecelerdeki fiili tecavüzlere ait olduğundan şüphe edilemez. 7. §'daki üç ayrı cismanî ceza da bunun gibidir (bk. 7, 3., 4. §; 21, 1. §). 
Bunlara karşlık, kendisine sebebsiz yere kötü muamelede bulunan babasını da oğul şikâyet edebilirdi. Buradaki sığır cezalan da suçun ağırlığına göre değişmekte ise de aksi hâldekilere nispetle oldukça hafifttir (4. § I). Tedip hakkı sııını aşarak oğlunu öldüren babanın cezası bütün mallarının müsaderesidir (4. § II). Ne yazıktır ki böyle müsadelerde. ailenin diğer üyelerinin zarar görmelerinin nasıl önlendiğini ve bu müsaderelerin maliye hesabına olmayıp da aile babasının malları üzerindeki tasarruf hakkının, mirasçılarnnı lehine elinden alınmaktan ibaret mi olup olmadığın bilmiyoruz.

Kayınana ve babanın geline karşı otoriteleri bilhassa önemli bir şekilde korunmuş olduğu hâlde damat hakkında hiçbir kaide konulma. mışır. Kayınana ve babasına karşı kendisini savunmaya kalkmış olan bir gelin tıpkı ana-babasına ağır bir tecavüzde bulunmuş oğul gibi cezalandırlmaktadır ( 3 kere 9 sığır). Bu ceza tabiatiyle kocası tarafindan ödenecektir. Kayınanasına karşı fiilen tecavüzde bulunan gelin bundan da aaha ağır bir şekilde cezalandırılmaktadır: malî cezadan başka tecavüzün ağırlığma göre değişen cismanî cezalar verilmektedir (7. §).

Buna karşlık kaymana ve-babaya gelin ve damat üzerinde bir tedip hakkı tanınmışıır. Bu hakkın kötüye kullanılması da cezalandırılmaktadır hem de kayınana, kaynbabaya verilen cezanın iki misline çarptınlmaktadır (6. §).

Kocanın kan tarafindan veya bir kannın diğer bir kan tarafından öldürülmesine en büyük ceza takdir edilmiştir (sakatlama ve esir olarak satma) diğer hâllerde ise durumun vehametine göre karar vermek işi mahkemeye bırakılmışır (5 §).

(II) (a) Yasa (1. Fr.) zina işliyeni ölümle cezalandırmıs, eski Tsaayin Biçik ise (3. Fr.) zani ve zaniyeye küçük sığır cezalannı yeter bulmuştur. 1640 yilı kanun koyuculan da zani ve zaniyeyi oldukça mütevazi ve mahkemeye teslimi gereken sığır cezalan ile cezalandırmayr yeter bulmuşlardır (8. § 1. F.). Unutulmamak lâzımdır ki, burada kadının ödemesi gereken cezayı, aldatmış olduğu kocası aile mallanndan ödemek mecburiyetindeydi. Bundan ötürü zinadan ötürü dava açılmış olması pek ender olmak gerekir.

Evli bir kadının ırzına tecavüzü kanun zinanın bir çeşidi olarak kdbul etmiştir. Çünkü burada suçlu olan, zina da her iki tarafa verilen cezayı yalnız başına ödemekle mükellef tutulmuştur. 
(II) (b) bakire (veya kadın) kaçırılmasında fiilin kızın veya kadının arzusu ile veya arzusu hlâfına oluşu kanun tarafindan bir tutuimuştur. Önemli olan şey burada bunlarm, kendileri üzerinde velâyet hakkı bulunan kimsenin arzusu hilâfına kaçırılmış olup olmamasındadır. Demek ki burada kaçınlmış olanın şahsî hürriyetinin ihlâl edilmiş olması değil, ana-baba veya koca tarafindan kullanılmakta olan velâyet hakkının ihlâl edilmiş olması, hele kadın kaçırmalannda bir işçi götürülmüş sayıldığından, kocanın iktisadî durumunun bozulmuş olması cezalandırılmaktadır. Çünkü böyle kocalann,-eğer kaçmış olan suçluyu yakalayıp sorumlu tutmak mümkün değil ise-herne şekilde olursa olsun zararlarının tazmin edilmesi gerekmektedir. Bunun için de suçlunun mallarn koca lehine müsadere edilir ve karısı da buna (her hâlde esir olarak) gene tazminat olmak üzere verilir. Ancak bazan suçlu bekâr ve fakir olabileceği veya ikametgâ. hı bilinmiyebileceği gibi, mesafelerin uzak oluşundan müsadere de imkânsız veya faydasız olabilir. İşte yalnız bu hâller için damadın kayınana ve babasından başlığı geri istemek hakkı tanınmıştır. Bu da imkânsız ise o zaman ne yapılacağını prens tayin edecektir (10. § II). Kadın kaçırrrken tutulan suçlu, zarar gören kocanın sosyal durumuna göre yükselen bir sığır cezası ile cezalandırılır (10. § I). Aynca suçlunun, kadını, kocasına geri vermek mecburiyetinde olduğundan A III, 5. § II'ye kıyas edilerek şüphe etmemek gerekir. "Yanında tutan" tâbiri böylece ve "geri vermiyen" demekten başka bir şey değildir.

Bir kızın kaçunlması veya gaspedilmesi bahse konu ise, o zaman cezaya esas olarak kızın ana ve babasının sosyal durumu alınmaktadır (9.§). Suçlunun ele geçirilememesi hâlinde burada ne yapılacağı hakkında bir kaide mevcut değildir. Bunun 'sebebi, kaçarak yakalanmaktan kưtulmuş olan suçlularn çok kere ya ülkenin dışında ve uzaklannda oturmaları, bundan ötürü de bunlara karşı malî cezalann uygulanmasının imkânsız olması olmalıdır (8).

8) Kalmuk kadınlarının kaçımlması hakkında Pallas şunları söylemektedir (I. Bölüm, S. 102) : “......... Kalmuk kadınları ev işi yapmaktan yorulmazlar, işte hem bundan ötürü hem de şehevî gayelerle bu kadınlar her firsatta Kırgızlar tarafından kaçırılırlar". Pallas'ın zamanında görülen bu hâl, kanunun yazıldığı daha karıșılk devirlerde haydi haydi görülürdü. 